\section{UK charities move to keep research fraud at bay}

Medical charities in Britain are urging universities and other research institutions to introduce explicit mechanisms for dealing with scientific fraud - including protection both for those accused of fraud and for whistleblowers.

The Association of Medical Research Charities (AMRC), which represents almost 100 charities and had a total budget of $£ 340$ million (\$565 million) last year, has approved a statement advising its members to insist that all institutions applying to them for funds have adequate procedures for handling cases of suspected fraud.

Government-funded research agencies, such as the Medical Research Council, are already introducing similar statements into their grant application processes. But AMRC officials believe that theirs is the first explicitly to include detailed suggestions of what such procedures should be. For example, they suggest a code of practice on standards of professional behaviour, provisions for staff training, and whistleblower protection. They also suggest that, if adequate steps are not taken to investigate suspected cases of fraud, the sponsoring charity should suspend the grant. If fraud is proven, grants should be terminated immediately.

Apart from a few well-publicized instances - such as that in 1995 in which a gynecologist at St George's Hospital in London was found guilty of altering data on the outcomes of an experimental method for treating ectopic pregnancies - cases of scientific fraud appear to be relatively rare in Britain. Because of this, many researchers question the need for new rules and fear that they would place an additional burden on universities. Michael Powell, for example, secretary of the research committee of the Committee of Vice-Chancellors and Principals, says that most universities already have "quite a lot of checks and balances" to prevent scientific fraud.

Others, however, claim that the relative lack of public exposure merely reflects the skill of institutions in discreetly covering up misconduct. Stephen Lock, a former editor of the British Medical Journal, says that according to a survey he published in the journal last year, half of professionals in medicine and surgery who were questioned said that they had known of instances of misreported results.

Recent cases of scientific fraud in the
US, as well as the federal government's sanctions against the institutions involved, have been closely watched in Britain. A spokesman for the Medical Research Council admits that US developments helped to persuade the council to introduce last September a requirement that institutions receiving its grants should have "adequate systems for assuring the quality of research".

In some cases the US influence has gone further. A code of research practice formally approved by the University of Edinburgh last December - believed to be the first in the United Kingdom to address the question of possible scientific fraud - explicitly models itself on parts of the1995 report of the US Commission on Research Integrity.

John Laver, vice-principal for research at Edinburgh and one of the code's key architects, says it was drawn up not because of direct experience of fraud, but because of a belief that higher education institutions should take an ethical lead. But he admits that there is an element of self-protection in the move and a desire by institutions to forestall the imposition of policies from outside.

DAVID DICKSON

London

\title{
Bid for pan-European allergy programme provokes controversy
}

Ambitious proposals for a coordinated European programme for the prevention and treatment of allergy are being discussed in Brussels. The move comes as a surprise to experts in international health policy who doubt that the European Union can influence member states' actions on specific diseases.

An unofficial document calling itself the European Allergy White Paper was presented to the European Parliament on 28 May. The report, written by 21 European allergologists, was financed and edited by the UCB Institute of Allergy, a health education institute in Brussels founded by the Belgian pharmaceutical company UCB, which makes antihistamines. The report has gained high-level support: Padraig Flynn, the Public Health and Social Affairs

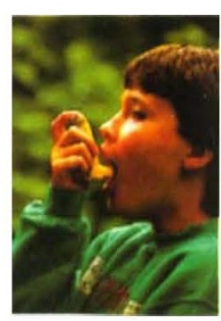

Commissioner, has welcomed it in a foreword.

Diane von Moerbreke, the report's editor at the UCB institute, rejected any suggestion that the pharmaceutical industry was lobbying politicians. "There is no per- sonal input from UCB," she said. Stephen Holgate, professor of immunopharmacology at the University of Southampton, England, and one of the authors, agreed that the report is independent and that its principles "are sound".

The document says that hayfever affects between 10 percent and 20 percent of Europeans, and that the prevalence of asthma in most states approximately doubled during the 1980s. It calls for member states to increase their allergy prevention efforts, for example by encouraging breast-feeding and banning smoking in public places. More controversially, it also wants "a system of centralised cross-border coordination in Europe" to achieve standard approaches to training, diagnosis, and treatment. Holgate says a coordinated approach to treating asthma in Britain has already reduced death rates.

But Martin McKee, a specialist in European health policy at the London School of Hygiene and Tropical Medicine, questions the power of the EU to act. "On the evidence available, it is not clear how any proposals for action on allergy are consistent with the EU's competence in public health," he says. Under the Maastricht Treaty, the EU has some limited powers in this field, but member states have primary responsibility. McKee is also sceptical about the way policies are set in Brussels. "There is a concern that European policy on a number of public health issues is driven more by the interests of industry than by Europeans' health needs," he says.

European programmes on cancer and AIDS were set up in 1988 and 1991, although without any clear legal basis. Since then most other proposals on specific diseases, for example on nutrition, have failed. In 1995, however, a vocal group of MEPs secured 5 million ECU (\$5.5 million) for research into Alzheimer's disease.

John Warner, professor of child health at Southampton University, who is unconnected with the report, said that allergy prevention would nevertheless benefit from international coordination, for example food labelling.

PHYLLIDA BROWN London 